\title{
Chlamydophila pneumoniae Antibodies in Swine
}

\author{
J. ČANDERLE ${ }^{1}$, L. POSPÍŠIL ${ }^{1}$, H. ŠTROBLOVÁ ${ }^{2}$, Z. VĚŽNÍK ${ }^{1}$ \\ ${ }^{1}$ Veterinary Research Institute, Brno, Czech Republic; \\ 2 Department of Clinical Microbiology, Faculty Hospital Brno, Brno, Czech Republic \\ Received July 23, 2004 \\ Accepted March 3, 2005
}

\begin{abstract}
Čanderle J., L. Pospíšil, H. Štroblová, Z. Věžník: Chlamydophila pneumoniae Antibodies in Swine. Acta Vet. Brno 2005, 74: 81-86.

Sera from 80 boars of various breeds, all semen donors, kept in one insemination station in northern Moravia, were tested for the presence of Chlamydophila pneumoniae antibodies. The employees of the insemination station suffering very often from respiratory diseases were repeatedly examined for a long-term, serologically demonstrated chlamydial infection. The sera of the animals were tested by enzyme-linked immunosorbent assay (ELISA) with a species-specific major outer membrane protein (cMOMP) Chlamydophila pneumoniae and with a genus-specific chlamydial lipopolysaccharide (cLPS) antigen respectively. The antibodies against chlamydial heat shock protein (cHSP60) have been proved as well. In the ELISA IgG test with species-specific Chlamydophila pneumoniae antigen (cMOMP) 18 sera $(22.5 \%)$ were positive and 11 doubtful $(13.7 \%)$ and with chlamydial genus specific antigen (cLPS) 26 sera (32.5\%) were positive, 15 $(18.7 \%)$ were doubtful, respectively. A positive result of ELISA with cHSP60 as antigen has been found in 26 sera $(32.5 \%)$ and 7 doubtful $(8.7 \%)$. Sera from the control group of four specific pathogen free pigs proved negative in all tests.
\end{abstract}

Boar, IgG antibodies, chlamydophilal antigens, chlamydial heat shock protein

Chlamydophila (formerly Chlamydia) pneumoniae (C. pneumoniae) is a primary pathogen in humans. Everett at al. (1999) proposed a reclassification of the family Chlamydiaceae into four genera, based primarily on comparative sequence analysis of rRNA genes, and included C. pneumoniae into genus Chlamydophila. Current research results suggest that of all Chlamydophilae species, $C$. pneumoniae plays the most important role in human pathology. It is the most frequent cause of respiratory infections and also probably one of the agents in pathological processes in other organs (e. g. joint inflammation, genital infection, etc.). It is also a very likely co-factor leading to atherosclerosis, broncho-pulmonary, cervical and ovarian carcinoma as well as some disorders of the central nervous system (Gran et al. 1993; Sriram et al. 1999; Wimmer et al. 1996; Wollenhaupt and Zeidler 1997; Wong et al. 1999; Paavonen 2000; Bernhard et al. 2001).

C. pneumoniae was isolated for the first time in 1965 from the conjunctiva of a Taiwanese child; the strain was marked TW-183. The second isolation from the throat of a student with a pharyngeal inflammation took place in 1983 and was marked AR-39. The original name of C. pneumoniae was TWAR agent (Ku o et al. 1986; Grayston et al. 1986). C. pneumoniae is the cause of a very cosmopolitan infection attacking most of the world-wide population more than once a lifetime.

Respiratory infections caused by $C$. pneumoniae are usually mild. Nevertheless, in a significant number of cases they can develop into a more serious disease (sinusitis, bronchitis, or complicated pneumonia) (Grayston et al. 1993). Another important discovery in recent years has shown that humans are not the only hosts in whom $C$. pneumoniae causes primary disease. Its presence in infections occurring in various animal species is being reported in an increasing number of cases.

\begin{tabular}{ll}
\hline Address for correspondence: & \\
MVDr. Jiř́ Čanderle, CSc. & Phone:+420 533 331417 \\
Veterinary Research Institute & Fax:+420 541211 229 \\
Hudcova 70 & E-mail:pospisil@ vri.cz \\
62132 Brno, Czech Republic & http://www.vfu.cz/acta-vet/actavet.htm
\end{tabular}


Successively, the C. pneumoniae strain was isolated from horses (Storey et al. 1993), koala bears affected by ocular and genital infection (Glas sick et al. 1996; Jacks on et al. 1999; Bodetti et al. 2000), Australian and African frogs (Berger et al. 1999; Reed et al. 2000; Hotzel et al. 2001), from a Tanzanian chameleon, a green sea turtle from the Cayman Islands, an iguana, puff adders and a Burmese python (Bodetti et al. 2002). All of the $C$. pneumoniae positive animals suffered from some form of illness typical for humans affected by this Chlamydophilal species. All animal strains also showed a significant similarity with the human C. pneumoniae strain (up to $100 \%$ ).

Sako et al. (2002) successfully demonstrated the presence of the $C$. pneumoniae antigen (immunohistochemically, electronoptically and by PCR) in atherosclerotic lesions of the aorta and coronary and splenic arteries of seven dogs suffering from atherosclerosis. B o detti et al. (2002) describe six cases of disease or death in different species of animals as a consequence of $C$. pneumoniae infections, which indicates that the source of this microbe in the natural environment could be mammals, amphibians, reptiles or other animals.

It is surprising that we have not yet managed to find a published report on the presence of C. pneumoniae in pigs given the fact that Chlamydia suis and other species of Chlamydia or Chlamydophila were identified in this animal species (Chlamydia trachomatis, Chlamydophila pecorum, Chlamydophila psittaci-Kalten b oeck et al. 1997; Schiller et al. 1997a, b; Busch et al. 2000). The pigs are a globally-distributed animal species and could be an important reservoir of certain microbial and viral pathogens. We began therefore to conduct serological research of antibodies to $C$. pneumoniae in boars from an insemination station in northern Moravia, the employees of which suffer for extensively from respiratory diseases probably caused by chlamydiae confirmed serologically (B azala and Renda 1992; Pospíšil et al. 1997).

\section{Materials and Methods}

Origin of samples

Blood samples were collected from 80 boars kept at one insemination station in northern Moravia. Blood was taken from the v. cava cranialis, using the sterile collection set for swine (Hemos H-03, GAMA, Czech Republic). After coagulation and centrifugation the sera were stored at $-70^{\circ} \mathrm{C}$. As negative control the sera from four pathogenfree three-month-old pigs (bred Large White from the institutional herd) were used. The sera were collected and stored in the same way.

Detection of chlamydial antibodies

For the quantitative detection of species-specific IgG antibodies the commercially enzyme immunoassay kit Chlamydia pneumoniae-IgG-sELISA medac (Medac, Germany), with the microtiter plates coated with $C$. pneumoniae major out membrane protein (a highly purified and species specific antigen - cMOMP) has been used. For the detection of chlamydial genus-specific IgG antibodies the commercially recombinant enzyme immunoassay kit (Chlamydia-IgG-rELISA medac) with chlamydial lipopolysaccharide (genus specific antigen cLPS) has been applied.

Finally, the IgG antibodies against the chlamydial heat shock protein $60 \mathrm{kD}$ (anti-cHSP ${ }_{60}$ ) by a recombinant enzyme immunoassay for the quantitative detection using genus specific the "cHSP60-IgG-ELISA medac" device were ascertained.

Preparation of the reagents and ELISA test procedure were performed in accordance with the recommendations of the manufacturer with the following exceptions: the rabbit anti-swine IgG with peroxidase (RASw/Px from Sevapharma, Czech Republic) as conjugate, and Ortho-Phenylene-diamine (OPD, BIO-RAD, France) as chromogenic substrate have been used. The swine serum for detection of the anti-cHSP60 antibodies was diluted to $1: 300$ by sample diluent (Medac).

The photometric reading of optical density (OD) at $490 \mathrm{~nm}$ (reference wavelength $630 \mathrm{~nm}$ ) by a DYNEX MRX Reader was performed. For the evaluation of the ELISA test we calculated the OD cut-off (absorbance) in positive and negative control samples. The positive and negative (the sera from four specific pathogen-free pigs proved negative in all ELISA tests) samples were compared with OD of positive and negative control human serum (Medac), which were conjugated with goat anti-human IgG (Medac). The reaction was ascertained as negative for OD lower than the cut-off index (1.8), which corresponds to the summation of the average OD in negative control samples and a $10 \%$ increase on half the difference between positive control OD and negative control OD. An OD between 1.8 and 2.0 was marked as doubtful, higher than 2.0 as positive.

The results obtained were analyzed by means of correlation analysis using the Microsoft Excel program by Windows. 


\section{Results}

The ELISA method detected, in the blood sera of 80 boars, IgG antibodies anti-species specific antigen of $C$. pneumoniae (cMOMP), with 18 positive cases $(22.5 \%)$ and 11 doubtful cases (13.7\%) see Table 1 . The IgG antibodies anti-Chlamydophilal genus specific antigen (cLPS) proved by ELISA were detected, with 26 positive sera $(32.5 \%)$ and 15 doubtful sera (18.7\%). Out of the 18 anti cMOMP C. pneumoniae positive boar sera, 13 $(72.2 \%)$ were also serologically positive for genus specific antigen (cLPS). The detection of the species specific antibodies anti- $C$. pneumoniae is in highly significant correlation with the detection of antibodies anti-chlamydial genus specific antigen $(\mathrm{r}=0.785 ; p<0.001)$. By the ELISA IgG antibodies anti- chlamydial specific heat shock protein $\left(\mathrm{cHSP}_{60}\right) 26$ positive sera $(32.5 \%)$ and 7 doubtful sera $(8.7 \%)$ from the 80 boars were found. Out of positive and doubtful sera anti- $\mathrm{cHSP}_{60}$ reacting sera a positive reaction with other chlamydophilal or chlamydial antigens was detected in $24(74.7 \%)$ sera as well.

Table 1. Chlamydial antibody tests in the serum of boars $(n=80)$

\begin{tabular}{|c|cccccr|}
\hline Test & $\begin{array}{c}\text { ELISA anti- } \\
\text { C. } \\
\text { pneumoniae }\end{array}$ & $\%$ & $\begin{array}{c}\text { ELISA anti- } \\
\text { Chlamydia } \\
\text { genus }\end{array}$ & $\%$ & & \multicolumn{3}{c|}{$\begin{array}{c}\text { ELISA anti- } \\
\text { cHSP }_{60}\end{array}$} & \multicolumn{1}{c|}{$\%$} \\
\hline Positive & 18 & 22.5 & 26 & 32.5 & 26 & 32.5 \\
Doubtful & 11 & 13.7 & 15 & 18.7 & 7 & 8.7 \\
Negative & 51 & 63.7 & 39 & 48.7 & 47 & 58.7 \\
\hline
\end{tabular}

\section{Discussion}

The detection of the anti-chlamydial antibodies in pig sera is carried out rather sporadically and if so, then it is in the form of complement fixation test (CFT), with genus specific chlamydial antigen. The insemination station supplying boars for the examination described here was noted in the study using CFT about chlamydophilal infection in employees suffering from frequent respiratory diseases (Bazala and Renda 1992; Pospíšil et al. 1997). In another study performed in this insemination station the high prevalence of genus specific chlamydial antibodies detected by means of CFT in the sera of boars has been ascertained (Věžník et al. 1996). There are varying opinions on the evaluation of the CFT. The problem lies in the low sensitivity and specificity of the respective test (Henning et al. 2002). Nevertheless the test will be very often used by many authors as screening (e.g. Trávníček et al. 2001).

Other serological chlamydophilal reactions, commonly used in human medicine, such as indirect immunofluorescent reaction, ELISA, Western blot and others, are rarely used in veterinary medicine and the same applies to exceptional work with various chlamydial antigens (cMOMP, cLPS or heat shock protein - cHSP). Despite the fact that various chlamydial infections have been detected in pigs, namely Chlamydia suis, Chlamydia trachomatis, Chlamydophila pecorum, and Chlamydophila psittaci (Schiller et al. 1997ab; Bus ch et al. 2000), so far we have been unable to find in the professional literature evidence of spontaneous $C$. pneumoniae infection. Only Liuba et al. (2003) and Pislaru et al. (2003) describe the development and consequences of experimental $C$. pneumoniae infection in pigs.

The high prevalence of species-specific antibodies anti-MOMP C. pneumoniae $(22.5 \%)$ in the sera from boars kept at the mentioned insemination station is surprising, though logical when juxtaposed to the frequent infectious diseases in the station's employees. The possibility of including non specific reactions into the 
evaluation cannot be excluded, but it is quite unlikely when using species specific antigen in the ELISA test, and strictly set cut-off index for optical density for the estimation of positive reactions. According to the producer of the diagnostic sets, the probable crossreactivity between different chlamydia species has been reduced by extracting a common component of all chlamydiae. ELISA is a suitable means of specific and exact diagnosis of Chlamydophilal infections nevertheless a dispute about the detection of anti- $C$. pneumoniae antibodies in the set of boar sera is possible. On the basis of serological examination only we are aware that we cannot rule out infection caused by $C$. suis, and/or by other members of Chlamydia family which were identified in pigs (Chlamydia trachomatis, Chlamydophila pecorum, Chlamydophila psittaci - Kaltenboeck et al. 1997; Schiller et al. 1997a,b; Busch et al. 2000). In accordance with the recent proposal for reclassification of the order Chlamydophilales the former porcine serovar Chlamydia trachomatis will be classified in presence as Chlamydia suis. The pathogenic strain Chlamydia suis has been used by Sachse at al. (2004) for a challenge respiratory chlamydiosis in pigs. The antibody against Chlamydia trachomatis in 80 boars examined by us were ascertained only in $4(5 \%$ - data not shown). C. pneumoniae infection in pigs based upon isolation of the pathogen, direct antigen detection or nucleic acid amplification tests (PCR or LRC) will be confirmed by us in near future as well. Isolation of the pathogen from cell culture normally needs $2-3$ subsequent or different type passages. According to our experience direct immunofluorescence assays and antigen enzyme immunoassays seem to be of lower sensitivity and specificity. The findings of this study provide further support for the thesis of a wide-spread, cosmopolitan and interspecies $C$. pneumoniae infection, resulting in a broad spectrum of diseases (Shor 2000; Bodetti at al. 2002; Pospíšil and Čanderle 2004) and represents a health hazard in humans combined with an interesting epidemiological problem for both wild as well as domesticated animals, with a primary impact for people.

\section{Protilátky proti Chlamydophila pneumoniae u prasat}

Séra 80 kanců různých plemen, dárců semene chovaných na jedné inseminační stanici, byla vyšetřena na př́tomnost protilátek proti Chlamydophila pneumoniae. U zaměstnanců stanice se dlouhodobě vyskytuje vysoká nemocnost s infekcí chlamydiemi potvrzenou sérologicky. Séra kanců byla vyšetřena enzymoimunoesejemi (ELISA) s třemi antigeny: rodově specifickým lipopolysacharidem chlamydií (cLPS), druhově specifickým proteinem vnější membrány (major outer membrane protein cMOMP) Chlamydophila pneumoniae a konečně s proteinem tepelného šoku chlamydií $\left(\mathrm{cHSP}_{60}\right)$. V ELISA testu IgG se specifickým antigenem Chlamydophila pneumoniae (cMOMP) bylo pozitivních 18 sér (22.5\%) a 11 dubiózních (13.7\%). V ELISA testu IgG s rodově specifickým antigenem (cLPS) bylo pozitivních 26 sér (32.5\%) a 15 sér bylo dubiózních (18.7\%). Pozitivní výsledek ELISA s cHSP60 jako antigenem byl u 26 sér $(32.5 \%)$ a u 7 dubiózní (8.7\%). Kontrolní séra prasat (SPF) byla ve všech testech negativní.

\section{Aknowledgements}

The authors thank the management and the employees of the insemination station for their assistance with collection of blood samples and of other material. This paper was conducted with the support of the Grant Agency of the Ministry of Health of the Czech Republic, (IGA MZ CR No. NH/7026-3).

\section{References}

BAZALA, E, RENDA, J 1992: Latent infection caused by chlamydias, which results in health problems for pig, cattle and sheep breeders. Berl Munch Tierärztl Wschr 105: 145-149

BERGER, L, VOLP, K, MATHEWS, S, SPEARE, R, TIMMS, P 1999: Chlamydia pneumoniae in a free-ranging giant barred frog (Mixophyes iteratus) from Australia. J Clin Microbiol 37: 2378-2380 
BERNHARD, J, LEHMANN, T, VILLIGER, PM 2001: Chlamydia pneumoniae: a cause of reactive arthritis? Schweiz Rundsch Med Prax 90: 2060-2063

BODETTI, TJ, TIMMS, P 2000: Detection of Chlamydia pneumoniae DNA and antigen in the circulating mononuclear cell fraction of humans and koalas. Infection and Immunity 68: 2744-2747

BODETTI, TJ, JACOBSON, E, WAN, C, HAFNER, L, POSPISCHIL, A, ROSE, K, TIMMS, P 2002: Molecular evidence to support the expansion of the host range of Chlamydia pneumoniae to include reptiles, as well as humans, horses, koalas and amphibies. Syst Appl Microbiol 26: 146-152

BUSCH, M, THOMA, R, SCHILLER, I, CORBOZ, L, POSPISCHIL, A 2000: Occurrence of Chlamydiae in genital tracts of sows at slaughter and their possible significance for reproductive failure. J Vet Med B 47: 471-480

EVERETT, KDE, BUSCH, RM, ANDERSEN AA 1990: Emended description of the order Chlamydiales, proposal of ParaChlamydiacae fam. nov. and Simkaniacae fam. nov., each containing one monotopic genus, revised taxonomy of the family Chlamydiacae, including a new genus and five new species, and standards for the identification of organisms. Int J Syst Bacteriol 49: 415-440

GLASSICK, T, GIFFARD, P, TIMMS, P 1996: Outer membrane protein 2 gene sequences indicate that Chlamydia pecorum and Chlamydia pneumoniae cause infections in koalas. Syst Appl Microbiol 19: 457-464

GRAN, J, HJETLAND, R, ANDREASSEN, AH 1993: Pneumonia, myocarditis, and reactive arthritis due to Chlamydia pneumoniae. Scand J Rheumatol 22: 43-44

GRAYSTON, JT, KUO, CC, WANG, SP, ALTMAN, J 1986: A new Chlamydia-psittaci strain, TWAR, isolated in acute respiratory-tract infections. New Engl J Med 315: 161-168

GRAYSTON, JT, ALDOUS, MB, EATON, A, WANG, SP, KUO, CC, CAMPBELL, LA, ALTMAN, J 1993: Evidence that Chlamydia pneumoniae causes pneumonia and bronchitis. J Infect Dis 168: 1231-1235

HENNING, K. SACHSE, K, GROSSMANN, E 2002: Evaluierung eines Antikörper - ELISAs für Schweineseren. Dtsch tierärztl Wschr 109: 449-450

HOTZEL, H, GROSSMANN, E, MUTSCHMANN, F, SACHSE, K 2001: Genetic characterization of Chlamydophila pneumoniae isolate from an African frog and comparison to currently accepted biovars. Syst Appl Microbiol 24: 63-66

JACKSON, M, WHITE, N, GIFFARD, P 1999: Epizootology of Chlamydia infections in two free-range koala populations. Vet Microbiol 65: 255-264

KALTENBOECK, B, SCHMEER, N, SCHNEIDER, R 1997: Evidence for numerous omp1 alleles of porcine Chlamydia trachomatis and novel Chlamydophilal species obtained by PCR. J Clin Microbiol 35: 1835-1841

KUO, CC, CHEN, HH, WANG, SP, CAMPBELL, LA 1986: Identification of a new group of Chlamydia-psittaci strains called TWAR. J Clin Microbiol 24: 1034-1037

LIUBA, P, PESONEN, E, PAAKARI, I, BATRA, S, FORSLID, A, KOVANEN, P, PENTIKAINEN, M, PERSSON, K, SANDSTROM, S 2003: Acute Chlamydia pneumoniae infection causes coronary endothelial dysfunction in pigs. Atherosclerosis 167: 215-222

PAAVONEN, J 2000: Chlamydia and cancer. Proc. Fourth Meeting of the European Soc. for Chlamydia Res., Helsinki, 239-240

PISLARU, SV, VAN RANST, M, PISLARU, C, SZELID, Z, THEILMEIER, G, OSSEWAARDE, JM, HOLVOET, P, JANSSENS, S, VERBEKEN, E, VAN DE WERF, FJ 2003: Chlamydia pneumoniae induces neointima formation in coronary arteries of normal pigs. Cardiovasc Res 57: 834-842

POSPÍŠIL, L, VĚŽNÍK, Z, DIBLÍKOVÁ, I, PEJČOCH, M 1997: The occurrence of the antibodies against the chlamydial antigen in human population of the Czech Republic. Epidemiol Mikrobiol Imunol 46: 13-17

POSPÍŠIL, L. ČANDERLE, J 2004: Chlamydia (Chlamydophila) pneumoniae in animals: A review. Vet. Med. Czech 49: 129-134

REED, KD, RUTH, GR, MEYER, JA, SHUKLA, SK 2000: Chlamydophila pneumoniae in a breeding colony of African clawed frogs (Xenopus tropicalis). Emerg Infect Dis 6: 196-199

SAIKKU, P, LAITINEN, K, LEINONEN, M 1998: Animal models for Chlamydia pneumoniae infection. Atherosclerosis 140: Suppl. 1, 17-19

SACHS, K, GROSSMANN, E, BERNDT, A, SCHÜTT, C, HENNING, K, THEEGARTEN, D, ANHENN, O, REINHOLD, P 2004: Respiratory chlamydial infection based on experimental aerosol challenge of pigs with Chlamydia suis. Comp Immunol Microbiol Infect Dis 27: 7-23

SAKO, T, TAKAHASHI, T, TAKEHANA, K, UCHIDA, E, NAKADE, T, UMEMURA, T, TANIYAMA, H 2002: Chlamydial infection in canine atherosclerotic lesions. Atherosclerosis 162: 253-259

SCHILLER, I, KOESTERS, R, WEILENMANN, R, KALTENBOECK, B, POSPISCHIL, A 1997a: Polymerase chain reaction (PCR) detection of porcine Chlamydia trachomatis and ruminant $C$. psittaci serovar 1DNA in formalin fixed intestinal specimens from swine. J Vet Med B 44: 185-191

SCHILLER, I, KOESTERS, R, WEILENMANN, R, THOMA, R, KALTENBOECK, B, HEITZ, P, POSPISCHIL, A 1997b: Mixed infections with porcine Chlamydia trachomatis and infections with ruminant Chlamydia psittaci serovar 1 associated with abortion in swine. Vet Microbiol 58: 251-260

SHOR, A 2000: The pathology of Chlamydia pneumoniae lesions in humans and animal models. Trends Microbiol 8: $541-542$ 
SRIRAM, S, STRATTON, CW, YAO, SY, THARP, A, DING, LM, BANNAN, JD, MITCHELL, W 1999: Chlamydia pneumoniae infection in the central nervous system in multiple sclerosis. Ann Neurol 46: 6-14

STOREY, C, LUSHER, M, YATES, P, RICHMOND, S 1993: Evidence for Chlamydia-pneumoniae of nonhuman origin. J Gen Microbiol 139: 2621-2626

TRÁVNÍČEK, M, KOVÁČOVÁ, D, ZUBRICKÝ, P, ČISLÁKOVÁ, L 2001: Serosurvey of sheep and goats to Chlamydia psittaci in Slovakia during the years 1996-2000. Vet Med - Czech 46: 281-285

VĚŽNÍK, Z, POSPÍŠIL, L, DIBLÍKOVÂ, I, ŚVECOVÁ, D 1996: The frequency of antibodies against Chlamydiae in animals in the Czech Republic. Veterinářství 46, 335-338 (in Czech)

WIMMER, MLJ, SANDMANN-STRUPP, R, SAIKKU, P, HABERL, RL 1996: Association of chlamydial infection with cerebrovascular disease. Stroke 27: 2207-2210

WOLLENHAUPT, J, ZEIDLER, H 1997: Klinik, Diagnostik und Terapie der Chlamydien-induzierten Arthritis. Akt Rheumatol 22: 176-182

WONG, YK, GALLAGHER, P.J, WARD, ME 1999: Chlamydia pneumoniae and atherosclerosis. Heart 81: 232-238 